\title{
Preface to the First Edition
}

Khubilai Khan was a real person. Though Samuel Taylor Coleridge's poem "Kubla Khan" persuaded many readers that Khubilai was a mythical or legendary figure, he was most assuredly an actor on the historical stage, who not only influenced China and much of Asia but also affected the course of European history. Many of his contemporaries throughout the world had heard of him, and he is mentioned in thirteenth- and fourteenth-century books written in a variety of languages. Similarly, artists from different lands painted his portrait. $\mathrm{He}$ is represented as a Mongol in formal Chinese paintings; as a typical Muslim potentate, with the dress and physical features of a caliph, in Persian miniatures; and as a European king, with a Caucasian appearance, in manuscripts of Marco Polo's account of his travels. Each civilization depicted Khubilai in its own light. As a result his fame spread throughout the world.

His life and career spanned the rise and decline of the Mongol empire. He was born in 1215, the year in which his grandfather Chinggis Khan seized Peking, and his death in 1294 coincided with the deterioration and dismemberment of the Mongol empire that had been gradually created from the early thirteenth century on. He was significant because he was the first of the Mongol rulers to make the transition from a nomadic conqueror from the steppes to effective ruler of a sedentary society. His reign in China witnessed the construction of a capital city, the development of a legal code and a new 
written script for all the languages in the Mongol domains, and court patronage of the theater, the arts and crafts, and science and medicine.

Despite Khubilai's role in Asian, if not world, history, he has not been accorded a serious biography. Walker Chapman has written a charming children's book about him, but it is based exclusively on English-language sources. The two Japanese biographies, by Otagi Matsuo and Katsufuji Takeshi, and the Chinese biography, by $\mathrm{Li}$ T'ang, have relied principally on the chinese accounts and have hardly consulted the Middle Eastern and European sources: I have found all four works useful and do not wish to detract from the authors' contributions. Yet there is room for a new scholarly biography of the Great Khan.

After I had completed the manuscript for this book, I came across a 1986 biography of Khubilai Khan by Chou Liang-hsiao. Although it is based only on Chinese sources, Chou's biography merely confirms the themes I present in this book.

One of the difficulties that previous biographers and I have faced lies in the sources. The majority of the official Chinese histories, the most voluminous of the sources, portrayed Khubilai as a typical Confucian ruler, not as a real human being. Anecdotes and personal information and vignettes were scarce. The prospects for a study of the life of Khubilai Khan thus appeared to be discouraging. Some years ago when I first conceived of a biography of the Great Khan, I initially read and translated the annals ( pen-chi) of his thirty-four-year reign in the Chinese dynastic history (Yüan shih). The annals consisted of an almost day-by-day description of official events at court--the visits of foreign envoys, the promotion of officials, and the announcement of domestic policies, for example. But they yielded few clues about Khubilai's personality and his ideas and programs. They emphasized Khubilai's bureaucratic role and offered but a glimpse of him as a person. A biography based merely on the Chinese records could not be written. Moreover, since the Mongol written language had just developed at the time of Khubilai's birth and no real tradition of historical writing existed, few if any contemporary native sources were at hand. Fortunately, other sources were available. Since the Mongol empire encompassed much of Asia, historians and travelers representing other cultures wrote about the Great Khan. The Persian historian Rashid al-Din, the Korean officials who compiled their own court chronicle, the Koryŏ-sa, and Russian, Arab, Armenian, and Syriac writers provided interesting and useful vignettes concerning Khubilai 
that supplemented the Chinese accounts. Similarly, the Venetian traveler Marco Polo wrote at great length and with abundant detail about Khubilai's court. This combination of sources offered sufficient details for a study of Khubilai's life and times. When there are gaps in our knowledge, I have so indicated. But I think the main features and themes of his life and career are discernible in the available sources.

Historical research and writing are, for the most part, solitary enterprises. A scholar spends much of his time alone in libraries or at home. Yet numerous organizations and individuals enable the scholar to pursue his research and facilitate his work. I have been fortunate enough to receive assistance and support that have proved invaluable in the completion of this book. I should like to take this opportunity to thank those who most directly influenced or helped me.

I am grateful to the National Endowment for the Humanities and the American Council of Learned Societies for awarding me fellowships to undertake the research and writing of this book. Their support permitted me the time and opportunity to travel to libraries and to the sites associated with Khubilai. The Harvard-Yenching Library at Harvard University, the East Asian Library at Columbia University, and the Library of Congress were the main repositories at which I worked. The librarians at all three of these great research centers were helpful and invaluable guides to the Oriental sources in their collections. Similarly, librarians at the Royal Library in Copenhagen, the Tóyō Bunko in Tokyo, and the National Palace Museum in Taipei facilitated my research, and I should like to thank them for their assistance and their courtesy. A number of museum curators offered vital leads for my studies. Dr. Thomas Lawton of the Freer Gallery of Art, Dr. Stan Czuma and Mr. Wai-kam Ho of the Cleveland Museum of Art, as well as curators at the Uzbek State Historical Museum in Tashkent, the State Historical Museum in Ulan Bator, the Kansu Provincial Museum in Lan-chou, and the British Museum, have provided encouragement and assistance at various critical stages, and I am grateful to them all.

Some of the ideas expressed in this book were first presented as speeches or lectures to a variety of scholars and laymen, and I wànt to thank these audiences for permitting me to test my hypotheses on them. The Columbia University Seminar on Traditional China, the Program in East Asian Studies at Princeton University, the Oriental Studies Program at the University of Pennsylvania, the East Asian Studies Program at the University of Toronto, the Harvard University 
Seminar on Inner Asia, the Middle Eastern Program at Ohio State University, the International Conference on Islam at the Hebrew University in Jerusalem, the East Asian programs at Oberlin College and at the University of Kansas, the Middle Eastern Center at the University of Chicago, and the Chinese Studies Program at the University of Ghent offered congenial forums for the discussion of Khubilai and his times. I should like to thank the participants at these meetings for their questions and comments, and I am particularly grateful to those scholars who invited me to attend and to address these sessions: Professor Hans Bielenstein of Columbia, Professor Frederick Mote of Princeton, Professor Susan Naquin of the University of Pennsylvania, Professor Wayne Schlepp at Toronto, the late Professor Joseph Fletcher, Jr., at Harvard, Professor Stephen Dale at Ohio State, Professor Rafi Israeli at the Hebrew University, Professor Dale Johnson at Oberlin, Professor Wallace Johnson at Kansas, Professor John Woods at the University of Chicago, and Professor Charles Willemen at Ghent. Dr. John Langlois, formerly of Bowdoin College, invited me to present a paper on Khubilai Khan and Islam at a scholarly conference on China under Mongol Rule, sponsored by the American Council of Learned Societies, and I convened a conference on International Relations in East Asia, Tenth through Fourteenth Centuries, also funded by the ACLS. The discussions at these sessions helped me clarify my ideas about Khubilai and his era. Speeches in front of general audiences at the Asia Society in New York City, Iona College, the Wilton Public Library in Wilton, Connecticut, the Cosmopolitan Club, the Brearley School, the Cathedral School, and the Fieldston School in New York were not only enjoyable but also stimulating. The questions at the end of these presentations compelled me to rethink some ill-founded assumptions.

Doris Tomburello typed this book with the same dispatch and accuracy that she has my previous writings. I am deeply grateful for her care in detecting a number of careless errors. Other friends or colleagues who have helped me include Professor Charles Peterson of Cornell, Professor Herbert Franke of the University of Munich, Mr. and Mrs. Gordon Derzon, Mrs. Debora Kramer, Mr. George Moulton, Dr. and Mrs. Stan Czuma, Dr. Andrew Nemeth of the University of Pennsylvania, Professor Hok-lam Chan of the University of Washington, Mr. Peter Stern, Mr. William Frost, Ms. Gretchen Dykstra, Joseph and Françoise Shein, Jane and Thomas Martin, and Drs. Dennis and Catherine Niewoehner. I am also grateful to Sheila Levine, 
Sally Serafim, and Susan Stone of the University of California Press for their valuable contributions to the book.

The members of my family helped to expedite the completion of this book. My parents, Mr. and Mrs. Joseph Rossabi, my brother and sister-in-law Mayer and Naomi Rossabi, my uncle, Clement Hakim, my mother-in-law, Mrs. John Herrmann, Sr., and my brother-in-law and sister-in-law, Mr. and Mrs. John Herrmann, Jr., provided shelter for my wife, my children, and me in New York in the early days of my research, and they assisted in numerous other ways as well. My daughter Amy and my son Tony helped in many ways-from offering words when I was stumped in my writing to baking cookies when I needed sustenance to playing ball when they decided I was too sedentary. My wife Mary deserves much of the credit for this book. She was its first reader and editor and its best critic. Like Khubilai's wife Chabi, she has proved to be an indispensable helpmate. For all this and much more, I am very grateful.

I should point out that the original manuscript of this book was over twice the present size. For additional details, the reader may consult it at the East Asian Library of Columbia University.

I have taken advantage of the issuance of the paperback edition to make some minor corrections or alterations. I wish to thank Professor Elizabeth Endicott-West of Harvard, Dr. David Morgan of the School of Oriental and African Studies, London University, and Professor Denis Twitchett of Princeton for their suggestions.

I have used the fourth printing of the paperback edition of the book to make some additional minor changes in the text and footnotes. I have also appended a list of Western language sources that have either been published or been brought to my attention since the completion of the book. Three useful secondary studies in Chinese have also appeared, and I wish to mention them: Hu-pi-lieh by Shen Hui-ju (Taipei, 1990); Yüan Shang-tu by Ch'en Kao-hua, et al. (Chilin, 1988); and Sung Meng (Yüan) kuan-hsi shih by Hu Chao-hsi and Chou Ch'ung-hua (Cheng-tu, 1992). A more complete listing of both Western and Asian sources will be provided in a multi-volume history of the Mongols that I am currently preparing for publication.

August, 1994

New York City 
This page intentionally left blank 